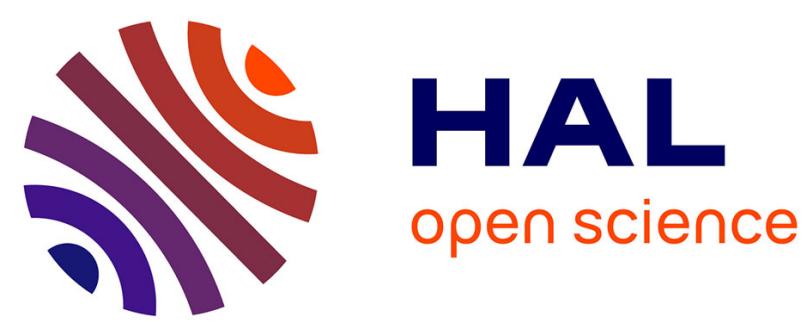

\title{
Pharmacokinetics partly explains the relationship between carcinoembryonic antigen level and survival of colorectal cancer patients treated with ramucirumab
} Sajida Ibrahim, William Raoul, Thierry Lecomte, Gilles Paintaud, David

Ternant

\section{To cite this version:}

Sajida Ibrahim, William Raoul, Thierry Lecomte, Gilles Paintaud, David Ternant. Pharmacokinetics partly explains the relationship between carcinoembryonic antigen level and survival of colorectal cancer patients treated with ramucirumab. European Journal of Cancer, 2018, 92, pp.119 - 120. 10.1016/j.ejca.2017.12.004 . inserm-01755511

HAL Id: inserm-01755511 https://www.hal.inserm.fr/inserm-01755511

Submitted on 30 Mar 2018

HAL is a multi-disciplinary open access archive for the deposit and dissemination of scientific research documents, whether they are published or not. The documents may come from teaching and research institutions in France or abroad, or from public or private research centers.
L'archive ouverte pluridisciplinaire HAL, est destinée au dépôt et à la diffusion de documents scientifiques de niveau recherche, publiés ou non, émanant des établissements d'enseignement et de recherche français ou étrangers, des laboratoires publics ou privés. 


\title{
Pharmacokinetics partly explains the relationship between CEA level and survival of colorectal cancer patients treated with ramucirumab
}

\author{
Sajida IBRAHIM ${ }^{1}$, William RAOUL ${ }^{1}$, Thierry LECOMTEE ${ }^{1,2}$, Gilles PAINTAUD ${ }^{1,3}$, David TERNANT ${ }^{1,3}$ \\ ${ }^{1}$ Université François-Rabelais de Tours, CNRS, GICC UMR 7292, Tours, France \\ ${ }^{2}$ CHRU de Tours, Department of Hepato-Gastroenterology and Digestive Oncology, Tours, \\ France \\ ${ }^{3}$ CHRU de Tours, Laboratory of Pharmacology-Toxicology, Tours, France
}

Corresponding author

William Raoul, william.raoul@univ-tours.fr

Université François-Rabelais de Tours, CNRS, GICC UMR 7292, 10 boulevard Tonnellé, BP 3223, 37032

Tours Cedex 01 ; Laboratoire de pharmacologie-toxicologie, CHRU de Tours, 2 boulevard Tonnellé, 37044 Tours Cedex 9, France

\section{Dear Editors,}

Yoshino and colleagues (1) recently reported results from the RAISE trial, in which 1072 metastatic colorectal cancer patients were treated with ramucirumab, a monoclonal antibody targeting vascular endothelial growth factor receptor 2 (VEGF-R2). They observed that low baseline serum levels of carcinoembryonic antigen (CEA) were associated with longer overall (OS) and progression-free (PFS) survivals. However, the authors did not discuss the possible mechanisms behind this association although the published literature may provide an answer.

First, Cohn and colleagues (2), using a subset of 907 patients from the same RAISE trial, observed that both low baseline CEA and high trough serum concentrations ( $\mathrm{Cmin}$ ) of ramucirumab were associated with longer OS and PFS. Second, Caulet and colleagues (3) reported similar results in metastatic colorectal cancer patients treated with bevacizumab, an anti-VEGF monoclonal antibody. These authors indeed reported that high bevacizumab $\mathrm{Cmin}$ was associated with longer OS and PFS. In addition, they observed that bevacizumab clearance increased with both high baseline plasma VEGF and high baseline serum CEA levels. The influence of plasma VEGF on bevacizumab clearance may be explained by target-mediated drug disposition, a mechanism frequently reported for monoclonal antibodies $(4,5)$. Because CEA level increases with tumour burden (6), it may constitute a biomarker of VEGF level in tumour microenvironment, a potent angiogenic factor that also increases with tumour volume (7). The increase of bevacizumab clearance with high serum CEA level, which led to low serum concentrations of bevacizumab, may therefore correspond to an elimination of the monoclonal antibody related to tumour VEGF.

Since VEGF-R2 expression was shown to be directly proportional to colorectal tumour doubling time in a preclinical model of xenografted mice (8) and VEGF-R2 promoter activity was significantly increased during the course of the disease in a mouse model of colitis-associated cancer (9), a positive correlation between tumour burden and amount of VEGF-R2 may reasonably be hypothesized. The association of CEA with both pharmacokinetics of ramucirumab and survival may be similar to bevacizumab. Increased serum CEA levels may represent higher tumour burden and 
should therefore correspond to increased VEGF-R2 expression. This may result in increased targetmediated elimination of ramucirumab, leading to underexposure and therefore to decreased clinical efficacy. As for bevacizumab, part of the relationship between serum CEA levels and survival of patients treated with ramucirumab may be explained by an increase in target-mediated disposition of the monoclonal antibody with tumour volume.

1. Yoshino T, Obermannova R, Bodoky G, Garcia-Carbonero R, Ciuleanu T, Portnoy DC, et al. Baseline carcinoembryonic antigen as a predictive factor of ramucirumab efficacy in RAISE, a secondline metastatic colorectal carcinoma phase III trial. Eur J Cancer 2017;78:61-69.

2. Cohn AL, Yoshino T, Heinemann V, Obermannova R, Bodoky G, Prausova J, et al. Exposureresponse relationship of ramucirumab in patients with advanced second-line colorectal cancer: exploratory analysis of the RAISE trial. Cancer Chemother Pharmacol 2017.

3. Caulet M, Lecomte T, Bouche O, Rollin J, Gouilleux-Gruart V, Azzopardi N, et al. Bevacizumab Pharmacokinetics Influence Overall and Progression-Free Survival in Metastatic Colorectal Cancer Patients. Clin Pharmacokinet 2016;55(11):1381-1394.

4. Azzopardi N, Lecomte T, Ternant D, Boisdron-Celle M, Piller F, Morel A, et al. Cetuximab pharmacokinetics influences progression-free survival of metastatic colorectal cancer patients. Clin Cancer Res 2011;17(19):6329-37.

5. Gibiansky L, Gibiansky E. Target-mediated drug disposition model for drugs that bind to more than one target. J Pharmacokinet Pharmacodyn 2010;37(4):323-46.

6. Wang WS, Lin JK, Lin TC, Chiou TJ, Liu JH, Fan FS, et al. Carcinoembryonic antigen in monitoring of response to systemic chemotherapy in patients with metastatic colorectal cancer. Int J Colorectal Dis 2001;16(2):96-101.

7. Kut C, Mac Gabhann F, Popel AS. Where is VEGF in the body? A meta-analysis of VEGF distribution in cancer. Br J Cancer 2007;97(7):978-85.

8. Solberg TD, Nearman J, Mullins J, Li S, Baranowska-Kortylewicz J. Correlation between tumor growth delay and expression of cancer and host VEGF, VEGFR2, and osteopontin in response to radiotherapy. Int J Radiat Oncol Biol Phys 2008;72(3):918-26.

9. Waldner MJ, Wirtz S, Jefremow A, Warntjen M, Neufert C, Atreya R, et al. VEGF receptor signaling links inflammation and tumorigenesis in colitis-associated cancer. J Exp Med 2010;207(13):2855-68. 